Terakreditasi Sinta 3 | Volume 3 | Nomor 3 | Tahun 2020 | Halaman 229-242

P-ISSN 2615-725X | E-ISSN 2615-8655

http://diglosiaunmul.com/index.php/diglosia/article/view/52

\title{
KETIDAKADILAN GENDER PADA PERNIKAHAN DALAM PEREMPUAN PATAH HATI YANG KEMBALI MENEMUKAN CINTA MELALUI MIMPI KARYA EKA KURNIAWAN
}

\author{
Gender Inequality in Marriage in Short Story Collection "Perempuan Patah Hatiyang Kembali \\ Menemukan Cinta Melalui Mimpi" by Eka Kurniawan \\ Anindya K. Wardani ${ }^{1, *}$ dan Maria Benga Geleuk ${ }^{2}$ \\ ${ }^{1,2}$ Magister Kajian Sastra dan Budaya, Fakultas Ilmu Budaya, Universitas Airlangga \\ Jalan Dharmawangsa Dalam, Surabaya 60286, Indonesia \\ 1,* Pos-el Korespondensi: anindyakusuma40@gmail.com \\ ${ }^{2}$ Pos-el: mbengageleuk@gmail.com
}

\begin{abstract}
Marriage is a sacred, religious, and has long-term purposes activity. Marriage is assumed as making a legal relationship between a couple within opposite sex. Rather than being a simple activity, marriage is a complex activity which has various aims that are teaching and taking care children, working together with the couple, and other happiness purposes. However, this picture of marriage seems missing in the work of Eka Kurniawan in the book of Perempuan Patah Hati yang Kembali Menemukan Cinta Melalui Mimpi. Through this book, the readers can see the opposite condition of marriage compared to marriage's stereotypes within the society. It also shows there are gender inequality practices throughout the story. Using Critical Feminism theory and descriptive-qualitative method, this research purpose is to analyze three short stories by Eka Kurniawan entitle (1) Gincu ini Merah, Sayang, (2) Cerita Batu, and (3) Pelajaran Memeliharan Burung Beo, to find how gender inequality depicted and the portrait of marriage which in the short stories. These three short stories show similar problem in a marriage which resulted in divorce. Through the process, this study found two main portraits of marriage in the works of Eka Kurniawan, that are (1) in marriage there are gender inequality practices which makes women suffer in various areas. (2) The relationship between male and female characters shows an unhealthy relationship in which women always suffers. Both result shows that marriage is not always about happiness, but its face bas been changed due to un bealthy relationship. In all un healthy marriage, woman always captures as the victims which legitimizing woman position as a submissive in a relationship even in the modern society.
\end{abstract}

Keywords: marriage, women, Perempuan Patah Hari yang Kembali Menemukan Cinta Melalui Mimpi, strory fact

\begin{abstract}
Abstrak: Pernikahan merupakan suatu praktik sakral, berlandaskan agama, dan memiliki tujuan untuk jangka panjang. Tujuan sebuah pernikahan bukanlah hal-hal yang menyenangkan saja melainkan juga mendidik dan menjaga anak, bekerja sama dengan pasangan, hingga tujuan kebahagiaan lainnya. Namun, dalam praktiknya pernikahan sering kali memiliki problema yang serius dalam ranah ketidakadilan gender. Pernikahan dan permasalahan ketidakadilan gender juga muncul dalam karya sastra. Oleh karena itu, penelitian ini dilaksanakan dalam rangka menunjukkan bagaimana gambaran ketidakadilan gender dalam pernikahan dan bagaimana representasi pernikahan. Dengan menggunakan studi deskriptif kualitatif dan teori kritik sastra feminis, peneliti akan mengkaji cerpen milik Eka Kurniawan dengan judul (1) Gincu ini Merah, Sayang, (2) Cerita Batu, dan (3) Pelajaran Memelihara Burung Beo yang terangkum dalam buku Perempuan Patah Hati yang Kembali Menemukan Cinta Melalui Mimpi. Ketiga cerpen tersebut menunjukkan permasalahan dalam lingkup pernikahan yakni hilangnya unsur tujuan harfiah pernikahan dan munculnya praktik ketidakadilan gender. Hasil dari penelitian ini menunjukkan jika posisi dan peran wanita dalam pernikahan menunjukkan adanya praktik-praktik yang merugikan wanita dalam berbagai bidang. Serta hubungan dengan tokoh laki-laki tidak menunjukkan adanya sikap positif yang juga merugikan pihak perempuan. Kedua hal ini merepresentasikan adanya perubahan nilai-nilai yang muncul di dalam pernikahan, yang awalnya memiliki nilai baik dan positif, pada teks ditemukan bahwa sebuah pernikahan menyisakan sebuah kesedihan dan
\end{abstract}


masalah. Penelitian ini juga menunjukkan jika di dalam sebuah hubungan pernikahan yang tidak baik atau berakhir selalu menjadikan wanita sebagai korban. Hal ini semakin melegitimasi jika wanita sebagai sosok yang submisif masih ada hingga saat ini meskipun dalam dunia yang modern.

Kata kunci: pernikahan, wanita, Perempuan Patab Hari yang Kembali Menemukan Cinta Melalui Mimpi, fakta cerita

\section{A. PENDAHULUAN}

Pernikahan merupakan sebuah kegiatan yang sakral dan menyangkut sebuah ikatan laki-laki dan perempuan ketika mereka menginjak dewasa yang berlandaskan agama (Saidiyah \& Julianto, 2016). Kehadiran pernikahan di tengah masyarakat tidak hanya sekedar melibatkan hubungan antara dua insan manusia saja, tetapi apa yang menjadi bagian dari pernikahan melibatkan berbagai macam hal yang perlu dicapai. Berbagai landasan bagi pernikahan bukan hanya legalisasi sebuah hubungan, tetapi juga membawa sebuah tujuan yakni hubungan seksual, mendidik dan menjaga anak, dan pembagian kerja antara suami dan istri (Duvall \& Miller, 1985). Dengan adanya berbagai macam landasan pernikahan, dapat dipahami jika sebenarnya pernikahan merupakan sebuah praktik yang kompleks.

Kompleksitas dalam pernikahan tidak hanya muncul karena landasan pernikahan, tetapi juga munculnya problematika yang ada di baliknya. Seperti adanya pernikahan dini yang ada di area Jawa Timur (BPS, 2016). Beberapa negara Timur Tengah yang menikahkan anaknya berdasarkan pubertas bukan berdasarkan umur menjadikan banyaknya anak perempuan yang masih di bawah umur telah menikah (Al-Hakimi \& McLaughlin, 2016).

Problematika dalam pernikahan pun sering muncul dalam karya sastra Indonesia. Telah tercatat, banyak buku karya penulis Indonesia menunjukkan fenomena pernikahan dan hal-hal yang menyelingkupinya. Sebut saja, Ayat-Ayat Cinta yang sempat fenomenal dengan mengangkat isu-isu poligami (Budiana, 2012). Kemudian, adanya fenomena pernikahan dini dalam cerpen Si Menem Beranak Bayi milik Ahmad Tohari dan Inem milik Pramoedya Ananta Toer (Dewi, 2018). Adanya potret mengenai pernikahan tidak jauh dari alasan karena karya sastra tidak lahir dari ruang hampa (Teeuw, 1988). Melalui perspektif sosiologi sastra pun dapat ditemukan sebuah justifikasi jika karya sastra merupakan sebuah rekaan yang ada pada masyarakat. Penggambaran tokoh yang ada pada fiksi juga di-design dengan jelas dan lengkap sehingga mereka memiliki sikap, sifat dan gambaran fisik (Rokhmansyah, 2018). Dengan demikian, penggambaran mengenai pernikahan yang ada di dalam karya sastra juga menunjukkan jika pernikahan tidak hanya sekedar hubungan sakral dua antara dua manusia dan landasan yang harus terpenuhi melainkan ia juga memiliki problematika yang menyelimutinya. Fenomena poligami dan pernikahan dini dalam karya sastra merupakan dua dari beberapa fenomena yang muncul dalam lingkup pernikahan.

Selain masalah yang ada di atas, problematika yang sering muncul dalam lingkup pernikahan, dalam karya sastra maupun tidak, seringkali berhubungan dengan masalah gender, yang salah satunya ialah problematika antara hubungan pria dan wanita dalam sebuah pernikahan. Hubungan antar gender sering muncul didasari oleh persepsi jika feminitas merupakan the other yang menyebabkan adanya perlakuan yang tidak adil. Simone de Beauvoir (1987) dalam bukunya The Second Sex yang menjelaskan pria menganggap bahwa wanita ditentukan dan dibedakan berdasarkan eksistensi pria, bukan karena diri seorang wanita. Pria didefinisikan sebagai subjek 
dan bersifat absolut, sedangkan wanita sebagai sosok the other (de Beauvoir, 1987, p. 16). Persepsi mengenai posisi dan keberadaan seorang wanita yang sebagai sosok the other inilah yang membuat posisi seorang perempuan berada di bawah lakilaki sehingga menimbulkan ketidakadilan dalam beberapa sisi. Posisi ini sering terbawa hingga ke berbagai ranah dan salah satunya dalam pernikahan. Meskipun kehidupan saat ini telah berubah, tetapi fenomena ini masih tetap ada.

Dalam karya-karya milik Eka Kurniawan, dapat dengan mudah ditemukan problematika dalam dunia pernikahan, yang salah satunya pada kumpulan cerpen Perempuan Patah Hari yang Kembali Menemukan Cinta Melalui Mimpi. Buku kumpulan cerpen ini terbit pada tahun 2015 berisi 15 cerpen karya Eka yang telah ditulis selama beberapa tahun terakhir. Keunikan muncul ketika setiap cerita saling menunjukkan topik yang sama dan fenomena yang sama, yakni berputar pada hubungan antara wanita, pria, dan cinta (Afrisia, 2015). Tidak jauh berbeda dengan karya-karya sebelumnya, nafas permasalahan yang muncul pada karya-karya ini bersumber dari masalah yang muncul pada masyarakat, terutama masalah hubungan perempuan dan lakilaki yang berakibat adanya ketidakadilan gender.

Dari lima belas cerita pendek di dalam buku Perempuan Patah Hari yang Kembali Menemukan Cinta Melalui Mimpi, peneliti memilih tiga cerpen dengan judul (1) Gincu ini Merah, Sayang, (2) Cerita Batu, dan (3) Pelajaran Memelibara Burung Beo. Ketiga cerpen tersebut dipilih karena memiliki gambaran permasalahan yang selingkung. Cerpen Gincu ini Merah, Sayang mengangkat cerita berakhirnya hubungan suami-istri yang juga mantan pelacur dan langganannya. Hancurnya hubungan rumah tangga mereka terjadi karena adanya prasangka-prasangka yang menyelimuti keduanya. Akhirnya, pernikahan merekalah yang menjadi korban. Cerita Batu merupakan salah satu cerpen yang unik, karena menarasikan cerita melalui sebuah batu. Batu tersebut menjadi saksi pembunuhan suami terhadap istrinya dengan tragis. Sang suami tega menenggelamkan istrinya untuk menikah dengan wanita lain. Pada cerpen Pelajaran Memelihara Burung Beo pun memotret hubungan pria dan wanita dalam ikatan pernikahan. Tokoh utama dalam cerpen ini merupakan seorang imigran perawat di Amerika yang menikah dengan anak band di Los Angeles untuk mendapatkan green card. Meskipun tidak bahagia dan tidak juga sedih, hubungan mereka harus berakhir dengan perceraian. Dapat dilihat jika ketiga cerpen tersebut menunjukkan tema dan masalah tokoh yang sama yakni permasalahan hubungan antar gender dalam lingkup pernikahan yang berujung dengan perpisahan serta hilangnya tujuan utama pernikahan. Kedua masalah dalam cerpen milik Eka juga mendasari adanya praktik ketidakadilan gender. Karena permasalahan ketidakadilan gender terus menerus muncul dan direproduksi ulang, maka penelitian mengenai problematika pernikahan, terutama dalam lingkup hubungan gender, sangat signifikan untuk dilakukan secara akademik. Alasan tersebut juga yang mendasari penelitian ini, yakni untuk mengungkap bagaimana ketidakadilan gender yang dialami oleh tokoh perempuan dalam lingkup pernikahan yang direpresentasikan melalui cerita pendek karya Eka Kurniawan.

Dalam dunia akademik, cerpen milik Eka sangat jarang diteliti, tercatat satu penelitian yang pernah dilakukan dengan membahas enam cerpen dari dalam buku ini. Dengan menggunakan teori Tzevan Todorov, penelitian yang dilakukan oleh Susilo menunjukkan adanya citra perempuan yang ingin dibangun melalui teks ini. Citra perempuan tersebut dilihat melalui bagaimana tokoh wanita mengalami kekerasan fisik. Dengan membedah sisi naratologi, Susilo 
menemukan jika citra wanita yang dominan pada teks ini ialah ketakutan, lemah, pasrah, dan tidak berdaya di bawah dominasi laki-laki (Susilo, 2018). Melalui penelitian ini, ranah kajian memang terfokus pada studi gender dengan bantuan teori milik Todorov. Namun, penelitian ini hanya sebatas menunjukkan citra wanita yang dikarakteristikkan sesuai dengan stereotip yang dipahami oleh masyarakat umum saja.

Dalam penelitian tersebut, dapat diketahui jika lingkup yang dilakukan adalah gender, namun fokus penelitian yang dilakukan dapat dikatakan berbeda. Penelitian Susilo menunjukkan citra wanita dalam kekerasan yang dibedah melalui teori struktur Todorov. Penelitian ini telah memerikan gambaran secara umum mengenai bagaimana wanita digambarkan melalui beberapa cerpen di dalamnya yang dapat disimpulkan menunjukkan sisi sebagai sosok yang submisif. Posisi dari penelitian ini akan melengkapi dan membahas lebih dalam tentang bagaimana ketidakadilan gender yang muncul pada cerpen milik Eka Kurniawan yang muncul dalam lingkup pernikahan. Untuk sampai pada pendalaman penjelasan, kritik sastra feminis akan digunakan untuk mengeksplor bagaimana ketidakadilan gender yang terjadi dalam pernikahan yang dialami oleh perempuan.

Kritik sastra feminis merupakan sebuah teori yang berkembang karena feminisme berkembang dengan pesat. Teori ini berkembang untuk mengidentifikasi bagaimana perempuan dimunculkan dalam sebuah karya sastra. Feminisme merupakan gerakan kaum perempuan untuk menyuarakan kesetaraan gender dalam berbagai macam lingkup seperti pendidikan hingga dunia kerja (Sugihastuti \& Suharto, 2010). Sedangkan kritik sastra feminis berakar dari keinginan para feminis untuk mengkaji karya penulis wanita dan melihat citra wanita di dalam karya penulis pria yang sering digambarkan sebagai sosok yang terkungkung dalam lingkup patriarkal (Djajanegara, 2000). Selain itu, tujuan lain dari kritik sastra feminis ialah melihat apakah sebuah karya sastra tersebut akan berpihak pada wanita atau tidak (Buana, 2009). Dalam penerapannya, kritik sastra feminis memiliki dua tahap, yakni mencari bagaimana kedudukan dan peran tokoh perempuan dalam sastra, ketertinggalan dalam segala aspek, maupun hubungannya dengan tokoh lakilaki yang memiliki hubungan dengan tokoh wanita yang diamati. Kemudian menentukan sikap penulis yang sedang dikaji (Djajanegara, 2000; Buana, 2009). Karena kesamaan tujuan penelitian yang mengarah kepada eksplorasi ketidakadilan gender dalam pernikahan, yang mana erat kaitannya terhadap posisi dan hubungan wanita dengan pria dalam lingkup pernikahan, sehingga dengan menggunakan teori tersebut penggambaran mengenai ketidakadilan gender yang muncul pada karya cerpen Eka Kurniawan dapat diidentifikasi.

\section{B. METODE}

Data primer yang digunakan ialah cerpen dari buku Perempuan Patab Hari yang Kembali Menemukan Cinta (PPHKMC) karya Eka Kurniawan yang terbit tahun 2015. Akan ada tiga cerpen yang akan dianalisis, yaitu (1) Gincu ini Merah, Sayang (GMS), (2) Cerita Batu (CB), dan (3) Pelajaran Memelihara Burung Beo (PMBB). Kajian sastra bandingan sesungguhnya merupakan kajian yang mengutamakan relasi antar teks-teks yang bersifat multidisipliner, yang mengeksplorasi perubahan, pergantian, pengembangan, dan perbedaan (Welleks \& Warren, 1956). Cerpen-cerpen tersebut dipilih karena sama-sama memotret kisah hubungan pria dan wanita dalam pernikahan dari sisi-sisi yang berbeda. Oleh Karena itu, ketiga cerpen tersebut diyakini menunjukkan ketidakadilan gender dalam lingkup pernikahan yang pada akhirnya mampu 
menunjukkan representasi dari sebuah pernikahan.

Tahap awal dalam melakukan analisis ialah melakukan pembacaan dekat yang akan terfokus pada posisi perempuan dalam pernikahan yang akan diidentifikasi melalui kedudukan, peran, maupun hubungannya dengan pria. Tahap selanjutnya, melakukan pembacaan bagaimana hubungan pria dan wanita dalam dilingkup pernikahan. Tahapan terakhir ialah merumuskan kesimpulan yang akan berisi bagaimana bentuk ketidakadilan gender yang ada dalam lingkup pernikahan. Namun, penelitian ini hanya akan sampai pada tahap eksplorasi penggambaran tokoh wanita dalam karya sastra dan tidak sampai pada pemaknaan dari posisi karya sastra.

\section{PEMBAHASAN}

Pada bagian pembahasan, langkah awal yang akan dilakukan ialah menganalisis bagaimana posisi identifikasi terhadap kedudukan, peran, dan hubungan dengan pria dalam lingkup pernikahan dari tiga cerpen milik Eka Kurniawan dalam buku PPHKMC dengan judul GMS, CB, dan PMBB, serta bagaimana hubungan antara tokoh perempuan dan laki-laki yang ada di dalamnya.

\section{Posisi Perempuan dalam Sebuah Pernikahan}

Berlatar belakang sebuah hubungan pernikahan, ketiga cerpen mengusung tokoh yang menempati kedudukan yang sama, yakni seorang istri. Pada GMS, tokoh wanita tersebut bernama Marni, selain itu ia mengakui jika dalam pernikahannya ia sebagai seorang ibu rumah tangga biasa dan sosok yang setia melayani suaminya. Dalam teks Marni mengakui dirinya sebagai seorang ibu rumah tangga saat salah tangkap karena dianggap sebagai pelacur. Ia juga sosok yang digambarkan akan mengenakan lipstik merah untuk suaminya, meskipun suaminya telah tidak memedulikannya (Kurniawan, 2015, pp. 14-15). Di dalam cerpen GMS, Marni dideskripsikan sebagai sosok yang setia menunggu suaminya meskipun ia tidak dipedulikan lagi olehnya. Kesetiaannya untuk selalu menjadi sosok yang siap melayani dan setia juga ditunjukkan bagaimana Marni selalu memoles wajahnya agar ia tampil cantik untuk suaminya. Lipstik merah merupakan kenangan saat Marni masih menjadi pelacur dan melayani Rohmat sebagai pelanggan, Marni yang masih menggunakannya menyimbolkan jika ia masih memosisikan dirinya layaknya dahulu, melayani suaminya. Dengan kata lain, Marni memiliki posisi sebagai seorang ibu rumah tangga dan sosok yang melayani suaminya.

Dalam CB wanita yang berperan sebagai istri dari pria yang membunuhnya tidak dijelaskan dengan mendalam latar belakangnya selain menyebutnya sebagai seorang istri. Secara umum, istilah istri secara langsung akan membawa persepsi tentang tugas sebagai seorang istri yang umumnya berupa kegiatan dalam ranah domestik. Kegiatan domestik yang dimaksud seperti mengurus kebutuhan rumah dan anak.

Pada PMBB, tokoh perempuan bernama Mirah menunjukkan perannya yang ganda dalam sebuah keluarga. Ia merupakan sosok ibu dan juga seorang tulang punggung keluarga. Seperti yang muncul pada kutipan berikut.

\footnotetext{
Biasanya Mirah akan terbangun pada pagi hari oleh keributan mereka, yang meracau meminta makan pagi, dan sesekali ingin berbagi kisah dari mimpi semalam. Mirah berdiri di ruang tengah rumahnya, memandangi sudut-sudut seharusnya burung-burung itu berada (Kurniawan, 2015, p. 146).

Kata kepala rumah sakit, pemuda itu bisa memperoleh tempat tinggal dan makan setiap hari. Jika Mirah mau menikahinya, pemuda itu bisa memperoleh tempat tinggal dan makan setiap hari (Kurniawan, 2015, p. 150).
} 
Kutipan pertama menjelaskan bagaimana Mirah disibukkan dengan keributan burung-burung. Burung tersebut merupakan simbol dari anak-anak Mirah. Melalui kegiatan yang Mirah deskripsikan setiap pagi, diketahui jika Mirah merupakan sosok ibu yang mengurusi anak-anaknya. Ia disibukkan dengan tugas rumah seperti mengurus anak dan menjadi teman anaknya. Kemudian melalui kutipan kedua, Mirah diketahui menjadi tulang punggung dari keluarganya dikarenakan suaminya tidak memiliki tempat tinggal maupun pekerjaan. Sehingga, Mirah yang berprofesi sebagai perawat akan memberikannya tempat tinggal dan memberinya makan setiap hari dari hasil kerjanya. Hal ini membuktikan jika Mirah berperan sebagai tulang punggung keluarga juga. Dengan adanya dua tugas yang Mirah miliki, menunjukkan jika Mirah memiliki kedudukan dan peran ganda dalam keluarganya.

Posisi perempuan yang digambarkan dalam sebuah pernikahan menunjukkan jika mereka adalah seorang korban. Korban sama-sama mendapatkan tindakan yang kurang adil. Ketidakadilan dalam teks Eka Kurniawan dikategorikan sebagai ketidakadilan gender, yang dapat berbentuk marginalisasi, subordinasi, kekerasan, burden, dan hal lainnya yang tidak menguntungkan salah satu gender di bidang apa pun (Kholis, Jumaiyah, \& Wahidullah, 2017). Ketiga cerpen ini menunjukkan bagaimana wanita menjadi korban melalui berbagai macam ekspresi.

Di dalam GMS, tokoh Marni yang menjadi korban atas pernikahannya dan akhir dari segalanya. Ia dikategorikan sebagai seorang korban karena Marni harus menerima konsekuensi dan dirundung kesedihan dan ketidakadilan dalam sebuah hubungan. Ketidakadilan yang pertama ialah ia dituduh dan tidak diberikan kesempatan untuk menjelaskan apa pun saat diceraikan. "Marni ingin menjelaskan, tapi tak tabu apa yang harus dijelaskan. Dan, Rohmat Nurjaman tampaknya tak menginginkan penjelasan" (Kurniawan, 2015, p. 16). Kemudian Rohmat pun memiliki sebuah prasangka buruk terhadap Marni yang belum terbukti. Prasangka yang tidak dikonfirmasi inilah yang berujung pada perceraian mereka. Dua poin ini menunjukkan jika Marni merupakan korban atas prasangka dan tuduhan tanpa penjelasan.

Sikap Rohmat yang tidak memberikan kesempatan Marni untuk berbicara dapat dikategorikan sebagai ketidakadilan, karena Marni seharusnya memiliki hak untuk berbicara dan memberikan keterangan terhadap apa yang ia lakukan. Ketika seseorang tidak diberikan hak dan mendapatkan kerugian atas hal tersebut dibidang apa pun, maka tindakan tersebut dapat dikategorikan sebagai ketidakadilan gender. Perilaku Rohmat menunjukkan bagaimana Marni dianggap sebagai sosok "the other" yang dianggap tidak penting eksistensinya, hingga hak untuk bersuara tidak diberikan.

Korban dalam cerpen $\mathrm{CB}$ pun juga muncul, yang menjadi korban seorang wanita yang dibunuh suaminya. Kondisi wanita tersebut ketika dibuang di sungai sedang tidak berdaya dan sekarat (Kurniawan, 2015, p. 78). Kondisi tak berdaya dan sekarat menunjukkan adanya aksi yang dilakukan oleh suaminya kepada wanita tersebut sebelum ia ditenggelamkan ke dalam sungai, yang diprediksi berupa kekerasan fisik juga. selain dalam bentuk fisik, korban wanita juga disakiti dari sisi lain, yakni perselingkuhan. Di dalam sebuah pernikahan, berselingkuh merupakan perbuatan yang tidak baik dan dapat menyebabkan banyak efek. Sehingga, seseorang yang dilukai secara fisik, diduakan, hingga dibunuh merupakan sosok korban dalam pernikahan. Dan ini adalah topik cerita yang muncul hingga akhir cerita.

Melalui narasi yang telah ditunjukkan di atas, tokoh wanita dalam $\mathrm{CB}$ 
dikategorikan sebagai korban karena mengalami kerugian yang berlipat ganda. Kerugian yang ia alami ialah hak untuk hidupnya dihilangkan oleh suaminya sendiri. Kemudian ia mengalami kekerasan fisik sebelum meninggal oleh suaminya sendiri. Kekerasan fisik ini membuat hidup wanita tersebut menghilangkan hak wanita tersebut untuk bahagia. Ketiga ia menjadi korban perselingkuhan oleh suaminya sendiri. Kejadian-kejadian yang dialami wanita tersebut bersifat merugikan dan berbentuk kekerasan batin serta fisik sehingga seorang wanita tidak mendapatkan kehidupan yang adil.

Pada PMBB, korban ditunjukkan melalui kalahnya seorang ibu dalam mendapatkan hak asuh anaknya dan ditinggalkan suaminya ketika sang suami telah mapan secara finansial. Ketika berjuang mendapatkan hak asuh anaknya, mirah mencoba mengumpulkan bukti bahwa ia mampu mengurus anaknya, melalui kutipan di bawah ini terdapat gambaran bagaimana Mirah merupakan sosok korban di dalam hubungan ini.

Para hakim berkeyakinan, masa depan anakanak itu lebih terbentang di tangan seorang ayah anggota band punk-rock. Mereka bisa memperoleh bukti dengan cara gampang, semua pemusik punk-rock di Los Angeles kaya raya. Yang lebih buruk dari semua itu, pemuda San Antonio itu menunjukkan bon pembayaran atas nama Mirah, yang membuat anak-anak kembar mereka disakiti di Sunset Strip Tattoo.

Sederhananya, meskipun ia seorang perawat, Mirah tak layak mengurus anak (Kurniawan, 2015, p. 154).

Dalam hal ini, setelah ia ditinggalkan yang menunjukkan bahwa ia juga korban dari hubungan suami istri, ia juga menjadi korban lagi ketika berhadapan dengan hakim untuk memperjuangkan hak asuh anak mereka. Ia menerima ketidakadilan karena cara pandang yang menyuperioritaskan seorang ayah. Padahal sosok ayah yang ada pada cerpen PMBB tidak menunjukkan tingkah laku yang mampu mengasuh anak. Kondisi pekerjaan Mirah yang cukup mapan pun tidak bisa dijadikan untuk mendapatkan hak-haknya, meskipun selama ini kebutuhan dan urusan finansial diurus oleh Mirah. Dua poin yang dijelaskan menunjukkan adanya ketidakadilan terhadap wanita. Karena adanya hal tersebut, Mirah menjadi korban dari adanya perceraian di dalam rumah tangganya.

Ketiga teks milik Eka menunjukkan jika posisi wanita selalu menjadi korban dari laki-laki. Ketiganya ditunjukkan melalui tiga cara, yakni tidak adanya kesempatan untuk bersuara, hilangnya hak hidup dan menerima kekerasan fisik serta batin. Kasus lebih parah terjadi pada teks terakhir yang menunjukkan jika wanita merupakan korban dari pria dalam rumah tangga serta hukum yang memihak pada pria. Kasus pada ketiganya berhubungan dengan dua gender yang berbeda, feminin yang direpresentasikan pada wanita, dan maskulin yang direpresentasikan melalui kehadiran pria, sehingga dapat dikategorikan sebagai ketidakadilan gender dalam lingkup pernikahan. Kesamaan praktik ketidakadilan gender pada tiga teks Eka termanifestasi dalam bentuk yang selalu merugikan perempuan dari berbagai macam sisi.

Selanjutnya, wanita dalam ketiga cerpen Eka digambarkan sebagai sosok yang submisif. Sifat submisif merupakan sebuah sikap dalam menyembunyikan perasaan serta keinginan, tetapi mengizinkan orang lain untuk menentukan pilihan (Atik, Özmen, \& Kemer, 2012). Sehingga, sosok submisif identik dengan ketidakberdayaan seseorang maupun tidak melakukan apa pun ketika orang lain melakukan hal-hal yang tidak ia inginkan. Apabila menganut pada pengertian tersebut, melalui ketiga cerpen tersebut posisi wanita selalu submisif di hadapan suaminya dalam berbagai macam kegiatan. Pada GMS sifat 
submisifnya ditunjukkan ketika suaminya memintanya untuk bercerai seperti yang terdapat pada kalimat berikut, "Marni ingin menjelaskan, tapi tak tabu apa yang harus dijelaskan. Dan, Robmat Nurjaman tampaknya tak menginginkan penjelasan" (Kurniawan, 2015, p. 16). Dalam kalimat tersebut cara Marni bereaksi telah dipengaruhi oleh suaminya yang tidak ingin mendengarkan alasan apa pun atas perceraiannya. Selain tidak tahu harus berkata apa pun, Marni juga tak berusaha menjelaskan maupun menyanggah keinginan suaminya atas dasar ketidakmauan suaminya, dan akhirnya membawa mereka ke dalam perceraian. Sikap Marni yang hanya menurut dan tidak membela diri menunjukkan ia bersikap submisif terhadap suaminya sendiri.

Dalam CB, terdapat kutipan yang menjelaskan, "Sore itu seorang lelaki menyeret seorang perempuan sekarat ke tepi sungai, lalu menggelindingkannya ke dalam perabu" (Kurniawan, 2015, p. 78). Dalam kutipan tersebut, perempuan ialah seorang istri dari lelaki yang menyeretnya. Aksi lelaki yang menyeret istrinya dan istrinya sedang sekarat menunjukkan jika lelaki tersebut memiliki dominasi terhadap istrinya. Sifat submisif direpresentasikan melalui kata sekarat dan diseret. Kedua kata tersebut menunjukkan jika ia tidak mampu melawan, atau bisa dikatakan ia juga tidak melawan tindakan kekerasan yang diberikan oleh suaminya sehingga ia menerima tindak kekerasan yang ia dapat dari suaminya.

"Lalu, datanglah para petugas dari biro
perlindungan hewan, merampas burung-
burung tersebut, saat mereka semakin mahir
bicara. Sejak saat itu Mirah tak pernah lagi
mendengar siapa pun memanggilnya
"Mama", dan tak seorang pun bisa
dipanggilnya "Nak" (Kurniawan, 2015, p.
155).

Di dalam kutipan dijelaskan jika ia tak bisa lagi menjadi seorang ibu dan merawat anaknya. Burung beo merupakan hewan yang telah dianggap anaknya merepresentasikan kondisi Mirah dan hubungannya dengan kedua anaknya. Mirah diceritakan kehilangan hak asuh anak setelah berpisah dengan suaminya setelah keberpihakan hukum terhadap sosok Ayah dalam merawat anak. Dalam teks, Mirah juga harus berpisah dengan peliharaannya yang telah dianggapnya sebagai anak karena hukum yang berlaku sehingga ia tak bisa menjadi seorang ibu lagi. Kegagalannya menjadi seorang ibu dikarenakan seorang hak asuh anak diambil oleh pihak lelaki menunjukkan jika perempuan merupakan sosok yang submisif di dalam lingkup keluarga, pernikahan, maupun hukum. Kondisi Mirah mirip dengan bagaimana seseorang dianggap sebagai sosok yang submisif, yang mana jalan hidup Mirah harus ditentukan pihak lain, ia kehilangan hak, hingga kerugian secara psikologis yang ia dapatkan. Dapat disimpulkan jika Mirah merupakan sosok yang submisif.

\section{Hubungan Perempuan dengan Tokoh Pria dalam Pernikahan}

Hubungan ketiga tokoh perempuan dengan lelaki yang mereka nikahi menunjukkan kondisi yang tidak baik. Kondisi yang tidak baik yang muncul pada ketiga cerpen milik Eka antara lain adanya toxic relationship, hubungan yang tidak dilandasi ketulusan dan cinta kasih, dan adanya akhir yang tragis.

Poin pertama yang menunjukkan hubungan antara tokoh wanita dengan tokoh pria ialah munculnya praktik hubungan yang tidak sehat antara suami dan istri. Hubungan yang tidak sehat biasanya dikenal dengan istilah toxic relationship. Toxic relationship sendiri merupakan praktik hubungan yang menyebabkan tidak adanya rasa aman, nyaman, kasih sayang, hingga tidak peduli karena adanya dominasi, trigger, dan objektifikasi (Solferino \& Tessitore, 2019).

Pada GMS menunjukkan adanya prasangka-prasangka yang muncul selama berhubungan. Baik dari pihak laki-laki 
maupun perempuan. Munculnya prasangka ini menunjukkan jika dalam sebuah hubungan tidak adanya rasa aman dan kasih sayang. Pada kasus GMS prasangka tersebut hingga menimbulkan objektifikasi dari tokoh pria, seperti yang muncul pada kutipan berikut.

\begin{abstract}
Rohmat Nurjaman tak pernah berhasil membuktikan kecurigaan atas istrinya. Bahkan, meskipun beberapa kal sengaja pulang mendadak, ia selalu menemukan istrinya ada di rumah, menunggunya. Hingga suatu pagi seorang perempuan dari dinas sosial meneleponnya dan ia merasa memperoleh cukup bukti untuk kemudian menghukumnya tanpa ampun dengan sebaris kalimat pendek:

"Sebaiknya, kita bercerai saja" (Kurniawan, 2015, p. 21).
\end{abstract}

Kutipan di atas menceritakan bahwa Rohmat merupakan sosok suami yang menunjukkan adanya prasangka negatif terhadap istri. Prasangka yang sebenarnya tak terbukti membuat Rohmat melakukan apa pun untuk memastikan perasaan tersebut. Banyak hal yang telah dilakukan namun tak membuktikan apa pun. Efek dari rasa ini ialah sebuah ketidaknyamanan diri dalam berhubungan dan ketidaktenangan sebuah hubungan. Sehingga, apa yang Rohmat lakukan merupakan sebuah bukti bahwa hubungan mereka merupakan hubungan yang toxic.

Teks CB mengandung adanya tindak kekerasan dan perselingkuhan. Suatu bentuk pembunuhan merupakan tindakan yang dikategorikan sebagai salah satu bentuk dari hubungan yang tidak sehat. Berkali-kali narasi mengenai pembunuhan pada teks CB dimunculkan pada tulisan ini. Kutipan berikut menunjukkan bagaimana seorang suami yang tega membunuh istrinya. "Itu pembunubnya! Itu pembunubnya! Lelaki itu yang membunub si perempuan dan membenamkannya dalam keadaan sekarat ke dasar sungai" (Kurniawan, 2015, p. 78). Tindakan seorang pria yang juga suami dari perempuan tersebut menunjukkan adanya kekerasan atau hubungan yang tidak baik di antara keduanya. Pembunuhan merupakan sebuah situasi yang menunjukkan adanya rasa yang tidak aman, terdominasi, dan tidak adanya kasih sayang. Poin-poin ini menunjukkan jika praktik pernikahan tokoh dalam CB menunjukkan adanya hubungan yang tidak sehat.

Teks PMBB menunjukkan adanya ketidakpedulian di dalam sebuah hubungan. Ketidakpedulian merupakan salah satu ciri dari hubungan yang tidak sehat. Ketidakpedulian ini muncul karena alasan mereka menikah bukan karena saling suka atau rasa cinta, tetapi karena saling menguntungkan. Mirah ingin mendapatkan green card, sedangkan pasangannya ingin memanfaatkan tempat tinggal dan makanan dari Mirah (Kurniawan, 2015, p. 151). Alasan pernikahan mereka karena saling menguntungkan membuat rumah tangga mereka tidak berjalan seperti sebuah hubungan yang semestinya. Hubungan seperti ini menghasilkan ketidakpedulian pasangan dan tidak adanya rasa kasih sayang. Kedua poin ini merupakan indikator dari sebuah hubungan yang tidak sehat.

Hubungan antara perempuan dan laki-laki dalam ketiga cerpen Eka menunjukkan jika mereka tidak dilandasi dengan cinta. Secara umum, sebuah pernikahan dimulai karena alasan ketulusan hari antara laki-laki dan perempuan. Pada dasarnya pernikahan merupakan hal penting dalam masyarakat dikarenakan berfungsi untuk memenuhi kebutuhan dalam hal cinta dan dicintai, memenuhi kebutuhan individu dalam berbagai sisi, hingga rasa bangga atas satu dengan lainnya (Özyiğit, 2017). Sedangkan, landasan hubungan yang muncul pada ketiga cerpen milik Eka tidak pernah memberikan jalan untuk tercapainya fungsi pernikahan karena pernikahan mereka tidak dilandasi oleh cinta maupun kasih sayang. 
Pada GMS, tokoh pria dan wanita mengawali hubungan saat bertemu di tempat pelacuran seperti yang terkutip melalui, "Awalnya bubungan mereka merupakan pertemuan ganjil antara pelanggan dan pelayan" (Kurniawan, 2015, p. 16). Bagaimana awal bertemunya Rohmat dan Marni karena Rohmat pelanggan setia Marni pada tempat pelacuran yang hampir setiap malam ia temui. Dikarenakan bertemu karena kebutuhan seksual dan uang, hingga jenjang pernikahan keduanya selalu dipenuhi dengan beban masa lalu dan juga seringnya muncul prasangka buruk satu sama lainnya. beban dan prasangka merupakan dua hal yang menunjukkan bahwa pernikahan tersebut tidak menunjukkan adanya perasaan bangga memiliki satu dengan lainnya. terlebih lagi alasan mereka bersama pada awalnya ialah karena pemenuhan nafsu belaka dan uang. Poin-poin tersebut tidak menjelaskan bagaimana pernikahan keduanya dipenuhi dan diawali oleh perasaan cinta dan kasih sayang. Dikarenakan tidak berlandaskan perasaan tersebut, pernikahan mereka juga gagal memenuhi kebutuhan cinta dan dicintai pasangannya.

Pada CB, hubungan antara tokoh perempuan dan laki-laki tidak berlandaskan ketulusan hati ataupun kebaikan. Poin ini terlihat karena alasan suami dari tokoh wanita membunuh karena istrinya dikarenakan ada keinginan menikah lagi dengan wanita lain. Sedangkan tokoh pria yang berhasil membunuh istrinya menikahi wanita yang hanya menginginkan hartanya (Kurniawan, 2015, p. 85;87). Pada CB, hubungan mereka tidak memiliki alasan untuk mencapai tujuan pemenuhan cinta dan rasa dicintai, karena yang diterima oleh istri adalah sebuah pengkhianatan oleh suami karena keinginannya untuk menikahi orang lain. Apabila sebuah hubungan didasari oleh cinta maka tujuan pernikahan akan tercapai. Namun, sebaliknya pada CB kebutuhan tersebut tidak terpenuhi sehingga pernikahan mereka tidak dapat dikatakan memiliki landasan cinta karena telah terjadi perselingkuhan bahkan pembunuhan sang istri.

Cerpen PMBB menunjukkan jika pernikahan tidak berlandaskan cinta melalui kutipan, "Buat Mirah, itu berarti green card dan babkan, kewarganegaraan. ... Seharusnya seseorang memang tidak kawin karena green card, katanya, ditujukan untuk dirinya sendiri" (Kurniawan, 2015, p. 150). Sangat jelas jika cerpen PMBB menunjukkan bagaimana tokoh Mirah pada akhirnya menikah dengan suaminya karena ingin mendapatkan kemudahan ijin untuk tinggal di Amerika. Alasan ini menjadikan hubungan antara Mirah dan suaminya dikarenakan pemenuhan kebutuhan semata. Sama seperti kemauan suami Mirah yang ingin dinafkahi oleh Mirah karena ia tak memiliki kekayaan dan pekerjaan. Alasan ini menunjukkan jika hubungan keduanya tidak dilandasi oleh ketulusan sebagaimana hubungan pernikahan pada umumnya yang dapat mengacu pada pemenuhan kebutuhan cinta dan dicintai.

Poin ketiga menunjukkan jika semua hubungan antara laki-laki dan perempuan selalu berakhir dengan kesedihan ataupun kesengsaraan. Padahal pada hakikatnya, pernikahan memiliki tujuan yang membahagiakan dan bertahan dalam jangka waktu selamanya (Agustian, 2013). Tidak ada tokoh yang hidup berdampingan lama dengan suaminya dan berakhir dengan kebahagiaan. Pada GMS, tokoh Marni dihadapkan pada kondisi keluarga yang tidak baik setelah penangkapan. "... Di atas sofa, tergeletak. koper berisi barang-barangnya. ... berkata pendek, "Sebaiknya, kita bercerai saja" (Kurniawan, 2015, p. 16). Kutipan pendek tersebut menunjukkan bagaimana akhir dari pernikahan Marni dengan adegan pengusiran dari rumah dan pernyataan bercerai dari suaminya. Pernikahan mereka yang belum lama dan belum 
dikaruniai anak itu pun harus berakhir setelah adanya salah paham di antara keduanya yang tidak pernah terungkap.

Tak jauh berbeda, pada CB hubungan pernikahan suami istri harus berakhir tragis dengan pembunuhan istri. Sebuah batu menjadi saksi atas kejadian tersebut dan melihat seorang lelaki menyeret seorang perempuan sekarat ke tepi sungai, lalu mengikatnya dengan batu dan menenggelamkannya ke dalam sungai (Kurniawan, 2015, p. 78). Tak hanya di sini saja, kisah $\mathrm{CB}$ pun masih menunjukkan adanya akhir tragis suami dan istri, di akhir cerita pembunuh istri di awal cerita dibunuh oleh istri mudanya karena alasan uang dan selingkuhan. Sang batu menjadi saksi dari tindakan istri itu yang tega menaruh kerikil agar suaminya terpeleset dan meninggal (Kurniawan, 2015, p. 87). Dua kisah rumah tangga yang berakhir dengan pembunuhan pasangan semakin mempertegas unsur bahwa pernikahan dalam cerpen $\mathrm{CB}$ selalu diakhiri dengan hal-hal yang tragis, baik diakhiri oleh seorang suami maupun diakhiri oleh seorang istri. Hal ini menunjukkan bahwa baik wanita maupun pria dapat membuat hubungan pernikahan berakhir.

Pada PMBB, akhir kisah rumah tangga yang berusia 5 tahun dan memiliki anak 3 harus berakhir pula di meja hijau. Alasannya adalah karena suami secara langsung menceraikan istrinya karena telah memiliki harta dan pekerjaan mapan. "... Setelah lima tabun menjadi suaminya, pemuda itu pergi. Tentu karena pemuda itu telah memiliki rumah dan pekerjaan" (Kurniawan, 2015, p. 150). Akhir dari hubungan suami istri yang sama muncul lagi pada teks PMBB yang menjelaskan jika setiap hubungan akan berakhir, namun apa yang ada di dalam teks PMBB menunjukkan adanya akhir yang tidak membahagiakan. Sehingga keseluruhan poin gambaran pernikahan berbeda jauh dari bagaimana tujuan awal pernikahan. Melalui ketiga akhir dari pernikahan dalam tiga cerpen Eka Kurniawan, dapat disimpulkan jika hubungan pernikahan yang ada selalu memiliki akhir, dan akhir itu bukanlah sebuah akhir yang membahagiakan. Semua pernikahan yang tertulis tidak ada yang mengundang senyuman di akhir. Hal ini jelas mengisyaratkan jika gambaran pertama dalam cerpen ini ialah pernikahan selalu memiliki akhir yang tragis.

\section{PENUTUP}

Tiga cerpen karya Eka Kurniawan dalam kumpulan cerpen Perempuan Patah Hati yang Kembali Menemukan Cinta Melalui Mimpi memiliki nafas problematik yang mirip satu dengan lainnya. Permasalahan yang ditekankan diambil melalui fenomena-fenomena sosial. Salah satunya masalah yang melingkupi pernikahan. Dengan menggunakan teori kritik sastra feminis, masalah yang muncul dalam lingkup pernikahan dilihat melalui posisi dan peran perempuan serta hubungannya dengan tokoh laki-laki. Melalui analisis deskriptif kualitatif ditemukan jika adanya sisi lain dari pernikahan yang ingin Eka sampaikan yakni munculnya praktik ketidakadilan gender.

Dalam cerpen GMN, CB, PMBB posisi perempuan dalam sebuah pernikahan digambarkan melalui tiga acara, yakni peran dalam rumah tangga, posisi perempuan sebagai korban, dan perempuan adalah sosok yang submisif. Peran dalam rumah tangga yang ditunjukkan identik dengan posisinya sebagai seorang ibu rumah tangga, yang secara umum akan dikaitkan dengan tugastugas domestik. Namun, pada PMBB dijelaskan jika selain mengurus urusan domestik dan mendidik anak, tokoh perempuan juga memiliki peran ganda sebagai breadwinner dalam keluarga. Perempuan yang menempati posisi sebagai korban dalam rumah tangga ditunjukkan melalui tindak kekerasan, sosok yang tidak mendapatkan keadilan untuk berbicara, dan perempuan yang harus kehilangan hak asuh anaknya karena kalah dengan posisi ayah yang dianggap 
lebih mampu merawat anak. Dan yang terakhir, posisi dan peran perempuan ditunjukkan melalui sosok submisif. Perempuan yang submisif muncul melalui bagaimana jalan hidup perempuan harus dikuasai dan ditentukan oleh suami mereka, antara lain pilihan untuk berpisah sepihak, ketidakberdayaan untuk membela diri saat mendapat tindak kekerasan, dan diambil alih anak-anaknya oleh hukum dan pihak suami. Posisi dan peran perempuan dalam pembahasan di atas mengarah kepada praktik ketidakadilan dalam ranah gender yang dialami oleh pihak perempuan.

Tak jauh berbeda dengan hubungan perempuan dan laki-laki dalam sebuah pernikahan yang ditampilkan dalam tiga cerpen milik Eka juga menunjukkan adanya perlakuan yang tidak adil pada salah satu gender. Ketidakadilan yang dialami oleh tokoh perempuan digambarkan melalui adanya toxic relationship yang merugikan pihak perempuan dalam berbagai ranah. Kemudian adanya hubungan yang tidak dilandasi dengan cinta dan kasih sayang yang membuat gagalnya tujuan pernikahan dalam memenuhi kebutuhan cinta dan dicintai. Kemudian, hubungan antara perempuan dan laki-laki dalam ketiga cerpen juga digambarkan selalu berakhir dengan tragis. Penggambaran yang ada dalam ketiga cerpen menunjukkan bagaimana potret pernikahan yang juga tidak memiliki akhir yang bahagia dan juga hubungan antara perempuan dan laki-laki juga menunjukkan adanya kerugian yang dialami oleh pihak perempuan.

Melalui penjelasan di atas, cerpen GMN, CB, dan PMBB menunjukkan jika representasi dari sebuah pernikahan bukanlah kebahagiaan, melainkan sebuah fakta kelam dan penuh dengan kesedihan yang dapat dilihat dari adanya ketidakadilan gender dalam posisi maupun relasi tokoh perempuan. $\mathrm{Hal}$ ini mendobrak stigma bahwa pernikahan merupakan sebuah ikatan yang memiliki nilai positif pada manusia. Namun, pada ketiga cerpen tersebut menunjukkan oposisi yang menunjukkan bahwa pernikahan bukanlah sesuatu yang bahagia seperti yang dikampanyekan happily ever after atau seperti yang terlihat pada tujuan dari pernikahan secara harfiah. Pernikahan juga direpresentasikan bukan sebagai sebuah awal kebahagiaan, namun pernikahan juga merupakan awal dari adanya masalah permasalahanpermasalahan gender. Dengan kata lain, wajah pernikahan sebenarnya telah bergeser yang awalnya suatu kebahagiaan, kini ditunjukkan sebagai suatu masalah dan penuh dengan kesengsaraan. Poin kedua yang dapat ditarik ialah di dalam pernikahan selalu muncul korban-korban atas apa yang dilakukan oleh pasangan. Ketiga cerpen tersebut menegaskan bahwa korban selalu wanita, bagaimanapun kondisi lingkungan dan peradaban, wanita masih menjadi objek untuk mengalami ketidakadilan dalam lingkup pernikahan. Hal ini semakin menegaskan jika permasalahan wanita sebagai korban dari hubungan dengan lawan jenis belumlah selesai. Meskipun peradaban dan lingkungan telah berubah, posisi wanita masih tetap sebagai the second sex.

\section{DAFTAR PUSTAKA}

Afrisia, I. (2015, April 27). Serpiban Cerita Sederhana Eka Kurniawan. Retrieved from

https://www.cnnindonesia.com/hib uran/20150427164728-241-

49545/serpihan-cerita-sederhanaeka-kurniawan

Agustian, H. (2013). Gambaran Kehidupan Pasangan yang Menikah di usia muda di Kabupaten Dharmasraya. Spektrum, 1(1), 205217.

http://ejournal.unp.ac.id/index.php /pnfi/article/view/1516

Al-Hakimi, H., \& McLaughlin, K. (2016). Debatable Marriages: Marriage and 
Child Marriage in Saudi Arabia. Marriage \& Family Review, 52(7), 654664.

https://doi.org/10.1080/01494929.2 016.1157119

Atik, G., Özmen, O., \& Kemer, G. (2012). Bullying and submissive behavior. Ankara University Journal of Faculty of Educational Sciences, 45(1), 191-208. https://dx.doi.org/10.1501\%2FEgif ak_0000001241

BPS. (2016). Kemajuan yang Tertunda: Analisis Data Perkawinan Usia Anak di Indonesia. Jakarta: Badan Pusat Statistik.

Buana, C. (2009). Sejarah, Teori, dan Aplikasi Kritik Sastra Feminis. AlTuras, 15(3), 257-278. http://journal.uinjkt.ac.id/index.php /al-turats/article/view/4270

Budiana, N. (2012). Polygamy in AyatAyat Cinta as Reflection in Islamic Culture. Prosiding The 4th International Conference on Indonesian Studies, 611618.

https://icssis.files.wordpress.com/2 012/05/09102012-49.pdf

De Bauvoire, S. (1987). The Second Sex. Harmondsworth: Penguine.

Dewi, N. (2018). Pernikahan di Bawah Umur dalam Cerpen Ahmad Tohari dan Pramoedya Ananta Toer. Aksara, 30(2), 173-188. https://doi.org/10.29255/aksara.v3 0i2.305.173-188

Djajanegara, S. (2000). Kritik Sastra Feminis: Sebuah Pengantar. Jakarta: Gramedia Pustaka Utama.

Duvall, E. M., \& Miller, B. C. (1985). Marriage and Family Development. New York: Harper \& Row.

Kholis, N., Jumaiyah, \& Wahidullah. (2017). Poligami dan Ketidakadilan Gender dalam Undang-Undang Perkawinan di Indonesia. Al-Ahkan 27(2),

195-212. http:/ /dx.doi.org/10.21580/ahkam. 2017.27.2.1971

Kurniawan, E. (2015). Perempuan Patah Hati yang Kembali Menemukan Cinta Melalui Mimpi. Yogyakarta: Penerbit Bentang.

Özyiğit, M. K. (2017). The Meaning of Marriage According to University Students: A Phenomenological Study. Educational Sciences: Theory \& Practices 17(2), 679-711. https://doi.org/10.12738/estp.2017. 2.0061

Rokhmansyah, A. (2018). Perilaku Sosial Tokoh Utama dalam Novel Pengakuan Pariyem Karya Linus Suryadi. Diglosia: Jurnal Kajian Bahasa, Sastra, dan Pengajarannya, 1(1), 29-44. https://doi.org/10.30872/diglosia.v $1 \mathrm{i} 1.7$

Saidiyah, S., \& Julianto, V. (2016). Problem Pernikahan dan Strategi Penyelesaiannya: Studi Kasus pada Pasangan Suami Istri dengan Usia Perkawinan di Bawah Sepuluh Tahun. Jurnal Psikologi, 15(2), 124-133. https://doi.org/10.14710/jpu.15.2.1 24-133

Solferino, N., \& Tessitore, M. (2019). Human networks and toxic relationships. MPRA Paper No. $95536 . \quad$ https://mpra.ub.unimuenchen.de/95536/

Sugihastuti, \& Suharto. (2010). Kritik Sastra Feminis Teori dan Aplikasinya. Yogyakarta: Pustaka Pelajar.

Susilo, E. D. (2018). Citra Perempuan dalam Kumpulan Cerpen Perempuan Patah Hati yang Kembali Menemukan Cinta Melalui Mimpi Karya Eka Kurniawan. Skripsi. Universitas Airlangga. http://repository.unair.ac.id/76166/

Teeuw, A. (1988). Sastra dan Ilmu Sastra. Jakarta: Grasindo.

Welleks, R., \& Warren, A. (1956). Theory of Literature. New York. 
